\title{
Effect of Acclimatization Temperature and Light Intensity on the Graft-Take of Cucumber Seedlings
}

El-Sayed G Khater*

Agricultural and Biosystems Engineering Department, Faculty of Agriculture, Benha University, Egypt

\begin{abstract}
The main aim of this work is to optimize the environmental condition for best grafting by control the temperature and light of grafting conditions. To achieve that was study the effect of ambient temperatures $\left(20,23,26\right.$ and $\left.29^{\circ} \mathrm{C}\right)$, light intensity (0,2500 and 5400 Lux) and type of tunnel (truss and flat) on stem diameter, shoot length, leaf area, shoot dry mass, grafted-take and energy consumption. The obtained results indicated that the average temperature was 20.45 , $23.61,27.01$ and $29.71^{\circ} \mathrm{C}$ at $20,23,26$ and $29^{\circ} \mathrm{C}$ ambient temperatures in truss tunnel, while, it was $20.61,24.21,27.53$ and $30.09^{\circ} \mathrm{C}$ at $20,23,26$ and $29^{\circ} \mathrm{C}$ ambient temperatures in flat tunnel. The stem diameter values were 4.626 and $4.476 \mathrm{~mm}$ in truss and flat tunnel under study with ambient temperature 20 to $29^{\circ} \mathrm{C}$ and light intensity 0 to 5400 Lux. The shoot length values were 8.254 and $8.131 \mathrm{~cm}$ in truss and flat tunnel under study with ambient temperature 20 to $29^{\circ} \mathrm{C}$ and light intensity 0 to 5400 Lux. The leaf area values were 56.074 and $53.214 \mathrm{~cm}^{2}$ in truss and flat tunnel under study with ambient temperature 20 to $29^{\circ} \mathrm{C}$ and light intensity 0 to 5400 Lux. The shoot dry mass values were 396.448 and $386.585 \mathrm{mg}$ in truss and flat tunnel under study with ambient temperature 20 to $29^{\circ} \mathrm{C}$ and light intensity 0 to 5400 Lux. The grafted-take values were 84.525 and $78.460 \%$ in truss and flat tunnel under study with ambient temperature 20 to $29^{\circ} \mathrm{C}$ and light intensity 0 to 5400 Lux. The energy consumed decreased with increasing ambient temperature and decreasing light intensity.
\end{abstract}

Keywords: Grafting; Temperature; Light intensity; Tunnel; Grafttake; Cucumber

\section{Introduction}

Cucumber (Cucumis sativus L.) is one of the most popular vegetables in the world, and annually about 71.4 million tons are produced [1]. Cucumber is a favorite commodity exports for markets and local consumption and represents one of the most important and economic vegetables in Egypt. It is grown in Egypt in the open field from March to November and under plastic houses from September to May. The total cultivated area of cucumber in Egypt was about 62073 feddan (25863.8 ha). This area produced about $587612 \mathrm{Mg}$ in 2015 according to [2]. Cucumber is also an important vegetable crop for greenhouse production in many countries. Continuous cultivation in greenhouses leads to some problems, including soil-borne diseases, soil nutrient imbalances, salty or alkaline soil conditions, spread of weeds, etc. To alleviate these problems, grafting is recommended. Grafting is an important technique for vegetable production in many countries where intensive and continuous cultivation is performed. Vegetable grafting has been used to improve yield, fruit quality and disease resistance in Solanaceae and Cucurbitaceae [3-6]. In recent years, grafting has been found effective in overcoming abiotic stresses.

Grafting is a horticultural technique whereby tissues from one plant are joined with another to obtain a combination of rootstock and scion genotypes that are more desirable than those contained in a single plant. Vegetable grafting is considered a sustainable pest and disease management practice that can improve fruit yields and quality as well as reduce environmental impacts with fewer chemical fumigants applied than in a non-grafted cropping system. Moreover, according to [4-7], grafted vegetables can exhibit excellent tolerance to both biotic stresses (e.g., soil-borne pathogens, foliar pathogens, arthropods and weeds) and abiotic stresses (e.g., low/high temperature, drought/flooding, heavy metal and nutrition). Even though grafting has been practiced in fruit trees for thousands of years, vegetable grafting has only recently been adopted on a commercial scale [8]. Interest in the use of grafted fruit vegetables has increased in Korea, Japan, and throughout Asia and
Europe, under intensive cropping systems. The purpose of vegetable grafting is to improve resistance to soil-borne pests and pathogens, adaptation to abiotic stresses, and growth and yield by promoting the absorption of nutrients $[9,10]$. Almost all cucurbits such as cucumbers, melons, and watermelons for greenhouse cultivation are being grafted in Korea. There is also an increasing trend in the grafting of solanaceous crops such as eggplants, peppers, and tomatoes [9]. In Egypt, about $10 \%$ of watermelon seedlings are grafted into various rootstocks and about 3\% of cucumber seedlings are grafted in 2013. The successful production of grafted transplants requires highly technical grafting skills and environmental control during healing and acclimatization period. Grafted transplants are produced by: 1) raising scions and rootstocks; 2) grafting; 3) healing and acclimatization; and 4) raising the grafted seedlings before transplanting. Healing and acclimatization are very important processes that are necessary for grafted plants to survive [9].

The use of grafting in fruit and vegetable production has been expanded in order to control pathogens and to enhance the plants' tolerance against abiotic stresses [5-7]. Highly technical grafting skills and environmental controls during the healing and acclimatization period are required for the successful production of grafted plants. Grafted plants were usually healed and acclimatized in the past under specific environmental conditions such as high relative humidity $(\mathrm{RH}$ $\geq 95 \%$ ) and low light intensity in order to produce a healthy plant that survived and grew [11]. However, several recent papers have reported

*Corresponding author: El-Sayed G Khater, Agricultural and Biosystems Engineering Department, Faculty of Agriculture, Benha University, PO Box 13736, Egypt, Tel: +20132467034/+20132467786; E-mail: alsayed.khater@fagr.bu.edu.eg

Received July 29, 2017; Accepted September 03, 2017; Published September 07, 2017

Citation: Khater ESG (2017) Effect of Acclimatization Temperature and Light Intensity on the Graft-Take of Cucumber Seedlings. J Environ Anal Toxicol 7: 502 doi: 10.4172/2161-0525.1000502

Copyright: @ 2017 Khater ESG. This is an open-access article distributed under the terms of the Creative Commons Attribution License, which permits unrestricted use, distribution, and reproduction in any medium, provided the original author and source are credited. 
that the photosynthesis, growth, and quality of grafted plants were improved by increasing the light intensity under highly controlled conditions during the healing and acclimatization periods $[12,13]$.

After grafting, it is important to control the environments around grafted seedlings for the robust joining of a scion and rootstock. Usually the shading materials and plastic film are used to keep the high relative humidity and low light intensity around grafted seedlings in greenhouse or tunnel. It is quite difficult to optimally control the environment for healing and acclimation of grafted seedlings under natural light. Therefore the farmers or managers rely on their experience for the production of grafted seedlings with high quality [14]. For successful grafting, control of the nursery's climatic conditions should be taken. A temperature of $25^{\circ} \mathrm{C}$ and $85-95 \%$ relative humidity should be provided within the growing conditions for good callus formation [15]. Several other environmental factors also affect the growth and development of the plants [16]. The most important of these factors are light, temperature, water (humidity) and nutrition. Light and temperature are two important parameters that affect the physiology of the grapevine. Plants need light and temperature for basic physiological processes such as photosynthesis, respiration, transpiration and carbohydrate assimilation $[17,18]$. Light is an essential factor for plant growth. Many studies have shown that both the light intensity and the light quality are important for the growth, development, pigmentation, and shape of plants $[19,20]$. Various types of artificial light have been used in plant production including fluorescent, metal halide, and high-pressure sodium lamps [21].

A non-grafted plant suffers a great deal of stresses from soil and foliar pathogens, weeds, low and high temperatures, drought and flooding, which in turn affect the growth and productivity. Grafting is the better solution to improve the resistance of plant to the stresses and also increase the plant tolerance for the inverse conditions as the grafting conditions is ensured. Therefore, the main aim of this work is to optimize the environmental conditions for best grafting by controlling the temperature and light of grafting conditions.

\section{Materials and Methods}

The experiment was carried out at SEKEM Company, Belbeies, ElSharkia Governorate, Egypt during 2015 season to study the influence of environmental parameters such as temperature and light intensity on grafting efficiency of the grafted cucumber plants.

\section{System description}

Figure 1 illustrates the grafting system description. It shows the system which consists of germination room, acclimatization room, trolleys, seedling trays, air conditioners, air blowers and grafted plants trays .

Germination room: After sowing, the trays were immediately transferred to the germination room (3 days). The germination room is made of concrete which was used for seeds germination. Its area is $137 \mathrm{~m}^{2}$ and has dimensions of $12.0 \mathrm{~m}$ long and $11.4 \mathrm{~m}$ wide. The room was provided with trolleys to carry the seedling trays, two air conditioners (Model Carrier 53 QH-B-Range temperature $15-40^{\circ} \mathrm{C}$-RPM 2800 -Power $5 \mathrm{hp} 380 \mathrm{~V} 50 \mathrm{~Hz}$, Italy) for control air temperature and sprinklers for increasing relative humidity of air. The trolley was made of galvanized steel metal of $3 \mathrm{~mm}$ thickness. Dimensions of trolley were $1.5 \mathrm{~m}$ length, $1.0 \mathrm{~m}$ width and $2.0 \mathrm{~m}$ high. The seedling tray holds 209 plants (11 rows of 19 cells) each cell measures $2.5 \mathrm{~cm}$ by $2.5 \mathrm{~cm}$ by $7.4 \mathrm{~cm}$ deep.

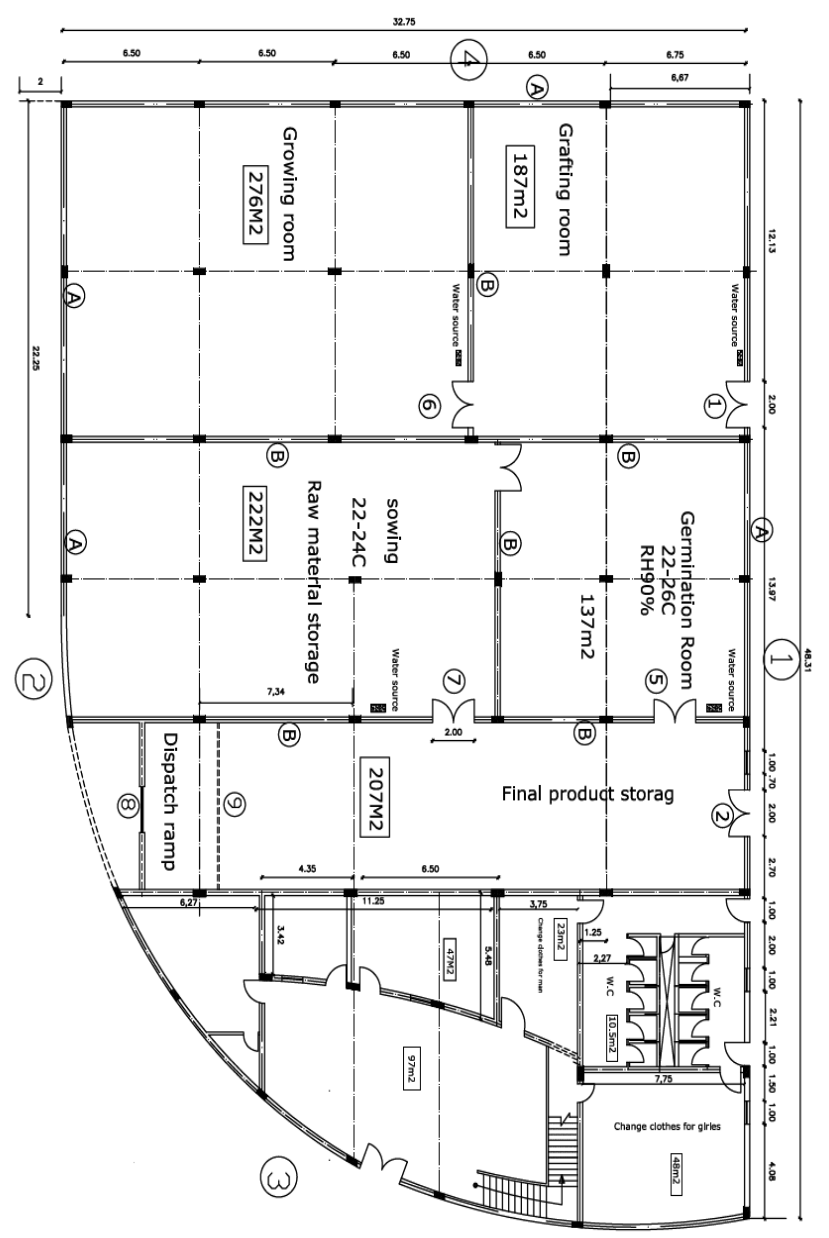

Figure 1: A plan of grafting location and description.

Acclimatization room: It is used to adapt the rootstock with scion. Its area is $276 \mathrm{~m}^{2}$ and has dimensions of $19.5 \mathrm{~m}$ long and $14 \mathrm{~m}$ wide. The room was provided with 35 trolleys to carry the grafted plants trays inner two types of tunnels (truss and flat tunnel), sex air conditioners for controlling air temperature and four air blowers (Model C.C.P. Parma-Flow Rate $1350 \mathrm{~m}^{3} \mathrm{~h}^{-1}$-RPM 2800-Power $2.5 \mathrm{hp} 380 \mathrm{~V} 50 \mathrm{~Hz}$, Italy) for moving air in the acclimatization room. The trolley was made of galvanized steel metal of $3 \mathrm{~mm}$ thickness. Dimensions of trolley are $3.0 \mathrm{~m}$ long, $1.5 \mathrm{~m}$ wide and $2.0 \mathrm{~m}$ high. Each trolley is provided with sex lamps (38 Watt) per shelf for lighting. The grafted plants tray holds 150 plants (10 rows of 15 cells) each cell dimensions of $4.0 \times 4.0 \times 6.2$ $\mathrm{cm}$. Figure 2 shows the dimensions of tunnels. Irrigation was carried out manually by hose. The amount of chemicals used in the irrigation system was as described by [22].

\section{Cucumber and rootstock seeds}

Cucumbers (Cucumis sativus L. cv. Joeun Baekdadaki) were used as scions while pumpkins (Cucurbita maxima D. $\times$ C. moshata D. cv. New Shintozwa) were used as rootstocks for producing grafted plants.

\section{Treatments}

The treatments include: ambient temperatures $\left(20,23,26\right.$ and $\left.29^{\circ} \mathrm{C}\right)$ nine temperature sensors were distributed in the tunnel as shown in Figure 3, light intensity were 0,2500 and 5400 Lux, tunnel types were 

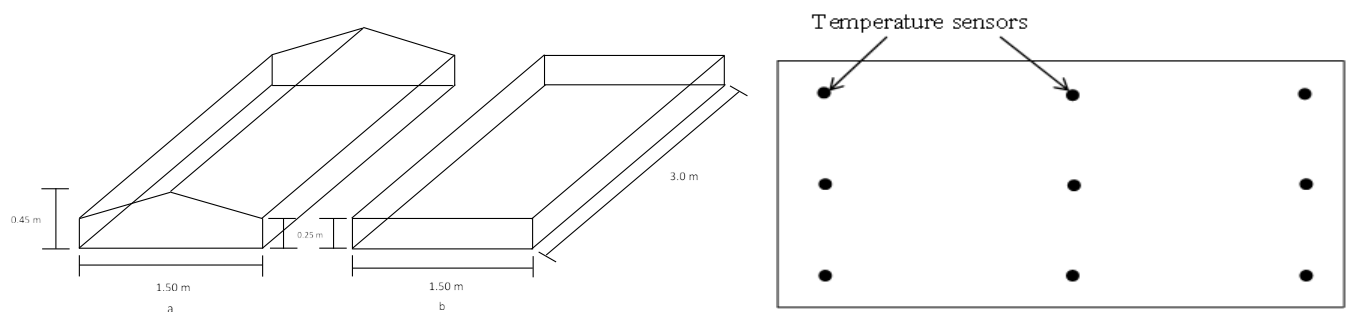

Figure 2: Schematic diagrams of tunnels under study (a: truss tunnel and b: flat); Distribution of temperature sensors in tunnel.

truss and flat types. Relative humidity was adjusted to be $92 \pm 2 \%$ and soilless media is white peat+perlite (70:30) was used. The experimental design was a split-split plot. Each treatment was replicated three times.

\section{Measurements}

Temperature and relative humidity were recorded by using a HOBO Data Logger (Model HOBO U12 Temp/RH/Light-Range -20 to $70^{\circ} \mathrm{C}$ and 5 to $95 \% \mathrm{RH}$, USA) every hour. Ten cucumber seedlings representing each replicate on day 8 after grafting were taken as recommended by [13] to determine stem diameter, shoot length, number of leaves, root volume and shoot and root dry weight. Fresh shoots and roots of seedlings were weighed and placed in drying oven with circulating air at $65^{\circ} \mathrm{C}$ for $48 \mathrm{~h}$ then weighed for dry weight. Also graft-take (efficiency of grafting) was calculated as follows (equation 1):

$$
\text { Graft }- \text { take }=\frac{\text { Number } \text { of surviving seedlings }}{\text { Number of grafted seedlings }} \times 100
$$

\section{Statistical analysis}

The statistical analysis for the data obtained was done according to [23] and the treatments were compared using Least Significant Differences (LSD) test at 95\% confidence level [24].

\section{Results and Discussion}

\section{Temperature}

Figure 3 shows the temperature distribution inside the flat and truss tunnels at different ambient temperature $\left(20,23,26\right.$ and $\left.29^{\circ} \mathrm{C}\right)$. For flat tunnel shape, it could be seen that the temperature distribution patterns appear as a concave shape where, the temperature increased toward the center of the flat tunnel which varies slightly from 20.291 to $21.053^{\circ} \mathrm{C}$ at $20^{\circ} \mathrm{C}$ ambient temperature, 23.526 to $25.761^{\circ} \mathrm{C}$ at $23^{\circ} \mathrm{C}$ ambient temperature, 26.893 to $29.517^{\circ} \mathrm{C}$ at $26^{\circ} \mathrm{C}$ ambient temperature and 29.149 to $33.729^{\circ} \mathrm{C}$ at $29^{\circ} \mathrm{C}$ ambient temperature. For truss shape tunnel, it could be seen that the temperature distribution patterns appears as a concave shape also where, the temperature increased toward the center of the tunnel which varies slightly from 20.259 to $20.909^{\circ} \mathrm{C}$ at $20^{\circ} \mathrm{C}$ ambient temperature, 23.271 to $24.300^{\circ} \mathrm{C}$ at $23^{\circ} \mathrm{C}$ ambient temperature, 26.699 to $27.811^{\circ} \mathrm{C}$ at $26^{\circ} \mathrm{C}$ ambient temperature and 29.372 to $30.818^{\circ} \mathrm{C}$ at $29^{\circ} \mathrm{C}$ ambient temperature. This could be due to the respiration heat produced by the plants.

\section{Seedling parameters}

Stem diameter: Table 1 and Figures 4-6 show the stem diameter of the grafted cucumber seedlings grown under two types of tunnels (truss and flat) as affected by ambient temperatures from 20 to $29^{\circ} \mathrm{C}$ and light intensities from 0 to $5400 \mathrm{Lux}$. Regarding of the effect room temperature, it could be seen that the average values of stem diameter were 4.404 ,
$4.599,4.735$ and $4.466 \mathrm{~mm}$ for the grafted cucumber seedlings grown at $20,23,26$ and $29^{\circ} \mathrm{C}$ ambient temperature, respectively depending on the light intensities and type of tunnel. The highest value of the stem diameter of the grafted cucumber seedlings $(4.735 \mathrm{~mm})$ was obtained at ambient temperature of $26^{\circ} \mathrm{C}$. The results revealed that the seedling stem diameter increased with increasing the ambient temperature from 20 to $26^{\circ} \mathrm{C}$. Grafting at $26^{\circ} \mathrm{C}$ room temperature gave the best results in terms of stem diameter for all light intensities and types of tunnel with significant differences. These results were in agreement with those obtained by $[25,26]$. Concerning the effect of light intensity on the stem growth, the results indicate that the average stem diameter of the grafted cucumber seedling grown under the truss was higher than that grown under flat tunnel, where, it recorded $4.381,4.553$ and $4.719 \mathrm{~mm}$ at 0,2500 and 5400 Lux light intensity, respectively. The results showed that increasing of light intensity during acclimatization to improve the growth and quality of grafted cucumber seedlings. These results agreed with those obtained by $[12,13]$ in which the stem diameter of grafted cucumber seedlings was enhanced by light during acclimatization. The results also indicate that the stem diameter ranged from 4.636 and $4.476 \mathrm{~mm}$ in truss and flat tunnel, respectively. The statistical analysis showed that the differences between the obtained data of stem diameter of cucumber seedlings due to the effect of ambient temperature, light intensity and type of tunnel were significant. The analysis showed also that the interaction between both $\mathrm{AB}, \mathrm{AC}, \mathrm{BC}$ and $\mathrm{ABC}$ were nonsignificant.

Shoot length: Table 2 and Figures 7-9 show the shoot length of the grafted cucumber seedlings grown under two types of tunnel (truss and flat) as affected by the ambient temperatures from 20 to $29^{\circ} \mathrm{C}$ and light intensities from 0 to 5400 Lux. Regarding of the effect ambient temperature, it could be seen that the average values of shoot length were $8.025,8.252,8.320$ and $8.174 \mathrm{~cm}$ for the grafted cucumber seedlings grown at $20,23,26$ and $29^{\circ} \mathrm{C}$ ambient temperature, respectively depending on the light intensities and type of tunnel. The results showed that the seedling shoot length increased with increasing the ambient temperature 20 to $26^{\circ} \mathrm{C}$, where, grafting at $26^{\circ} \mathrm{C}$ ambient temperature gave the best results in terms of shoot length for all light intensity and type of tunnel with significant differences. Concerning the effect of light intensity on the shoot length, the results indicate that the average shoot length of the grafted cucumber seedling grown under the truss and flat tunnel shape decreases with increasing the light intensity. It indicates that when the light intensity increased from 0 to 5400 Lux, the average shoot length of the grafted cucumber seedling significantly decreased from 8.326 to $8.101 \mathrm{~cm}$. These results agreed with those obtained by [13] in which the shoot length of grafted cucumber seedlings was decreased by light during acclimatization. The results also indicate that the shoot length ranged from 8.254 and 8.131 $\mathrm{cm}$ at truss and flat tunnel, respectively. The statistical analysis showed that there were non-significant differences between the temperature 
Citation: Khater ESG (2017) Effect of Acclimatization Temperature and Light Intensity on the Graft-Take of Cucumber Seedlings. J Environ Anal Toxicol 7: 502. doi: 10.4172/2161-0525.1000502

Page 4 of 10

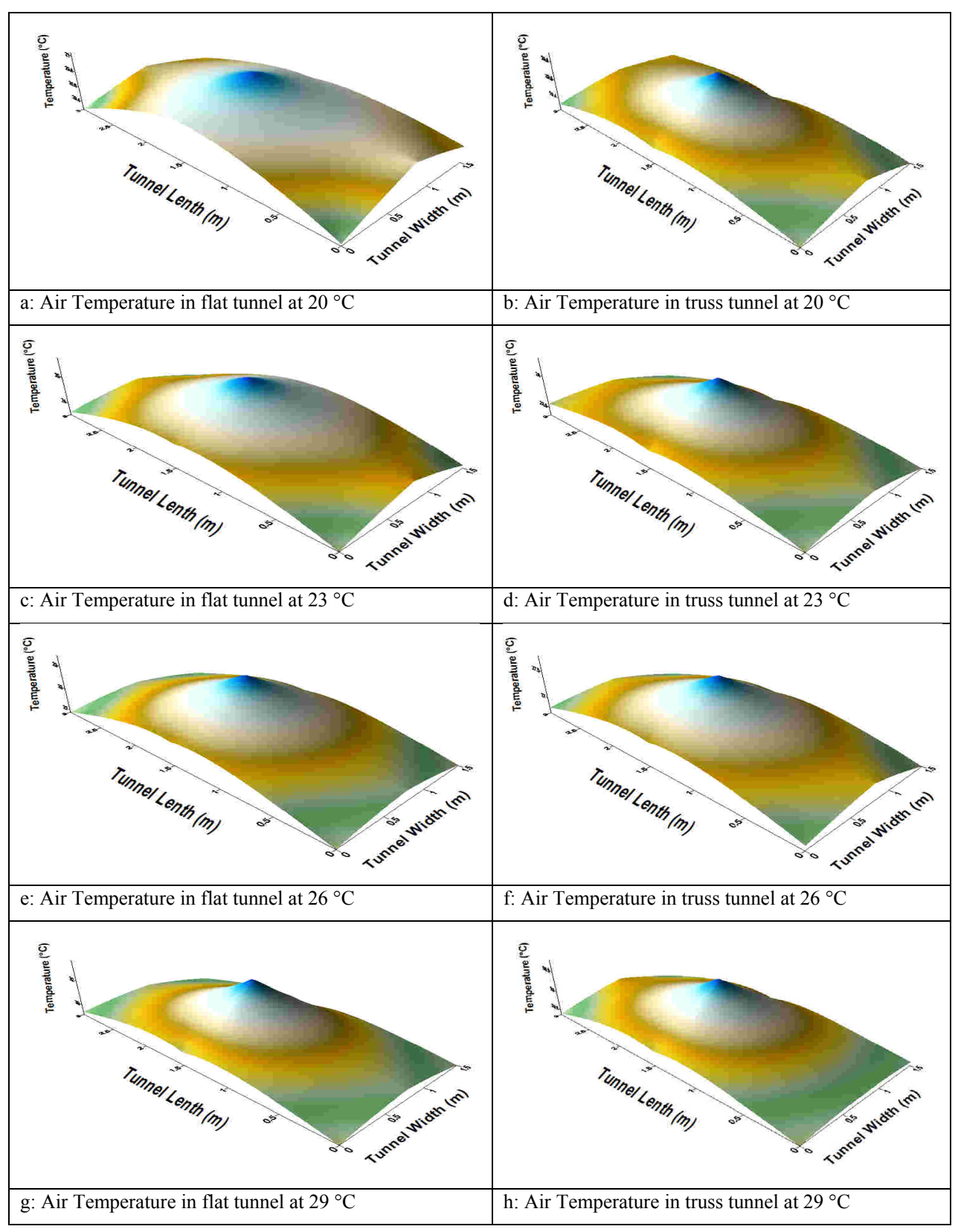

Figure 3: Distribution of temperature in flat and truss tunnels at different ambient temperatures.

treatments, while the differences between the obtained data of shoot length due to the effect of light intensity and type of tunnel shape were significant. The analysis showed also that the interaction between both $\mathrm{AB}$ and $\mathrm{ABC}$ were non-significant. On the other hand, the interaction between the effect of both $\mathrm{AC}$ and $\mathrm{BC}$ on the data were significant.

Leaf area: Table 3 and Figures 10-12 show the leaf area of the grafted cucumber seedlings grown under two types of tunnel (truss and flat) as affected by the ambient temperatures from 20 to $29^{\circ} \mathrm{C}$ and light intensities from 0 to 5400 Lux. It could be seen that the average values of leaf area were 51.098, 55.399, 58.286 and $53.793 \mathrm{~cm}^{2}$ for the grafted cucumber seedlings grown at $20,23,26$ and $29^{\circ} \mathrm{C}$ ambient temperatures, respectively depending on the light intensities and type of tunnel. The results showed that the seedling leaf area increased with increasing the ambient temperature 20 to $26^{\circ} \mathrm{C}$, where, grafting at $26^{\circ} \mathrm{C}$ ambient temperature gave the best results in terms of leaf area for all light intensities and types of tunnel with significant differences. These results were in agreement with those obtained by $[25,26]$. Concerning the effect of light intensity on the leaf area, the results indicate that the average leaf area of the grafted cucumber seedling grown under the truss and flat tunnel shape increases with increasing the light intensity. It indicates that when the light intensity increased from 0 to 5400 Lux, the average leaf area of the grafted cucumber seedling significantly increased from 50.682 to $59.150 \mathrm{~cm}^{2}$. Plants grown under high light intensity condition have higher photosynthetic capacity, greater leaf area, and more chloroplasts in mesophyll cells. The amount of chloroplasts increased with increasing light intensity during 
Citation: Khater ESG (2017) Effect of Acclimatization Temperature and Light Intensity on the Graft-Take of Cucumber Seedlings. J Environ Anal Toxicol 7: 502. doi: 10.4172/2161-0525.1000502

Page 5 of 10

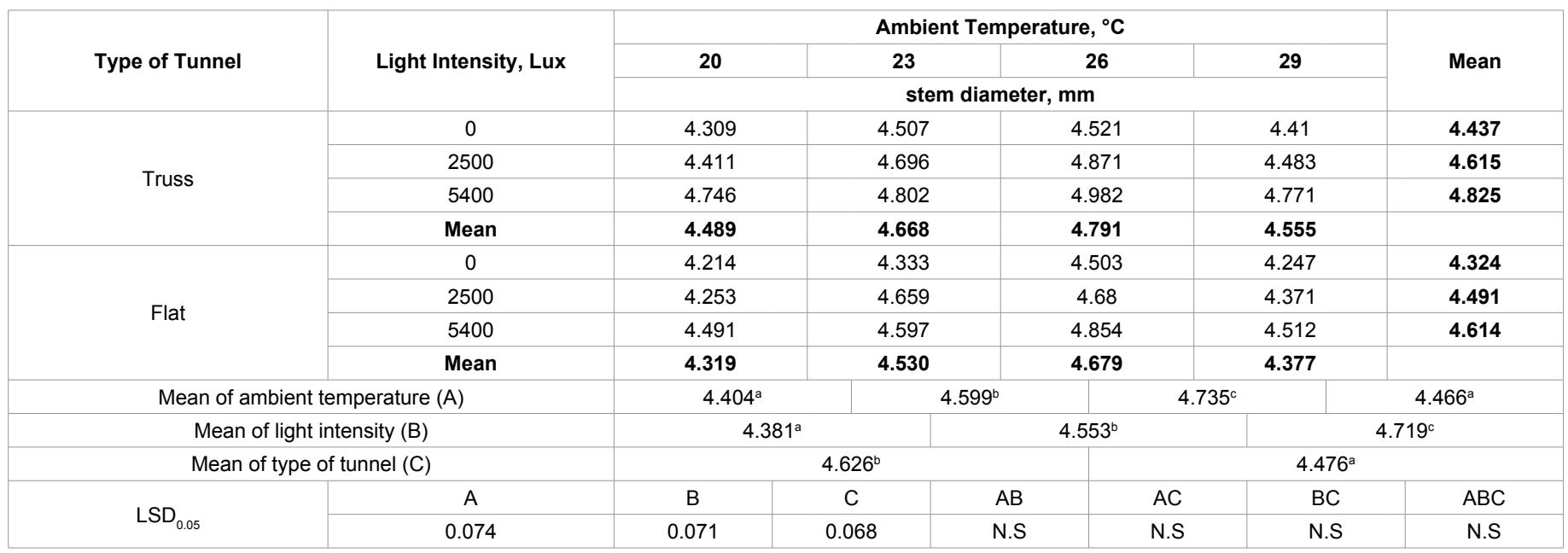

Table 1: Effect of ambient temperature, light intensity and type of tunnel on stem diameter of the grafted cucumber seedlings.

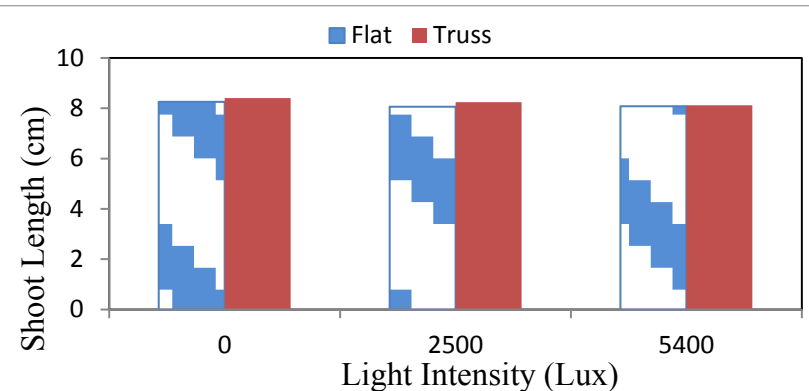

Figure 4: Effect of light intensity and type of tunnel on stem diameter of the grafted cucumber seedlings.

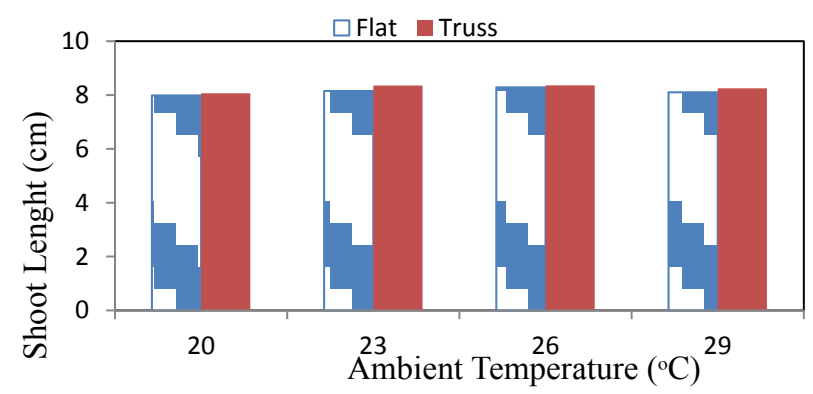

Figure 5: Effect of ambient temperature and type of tunnel on stem diameter of the grafted cucumber seedlings.

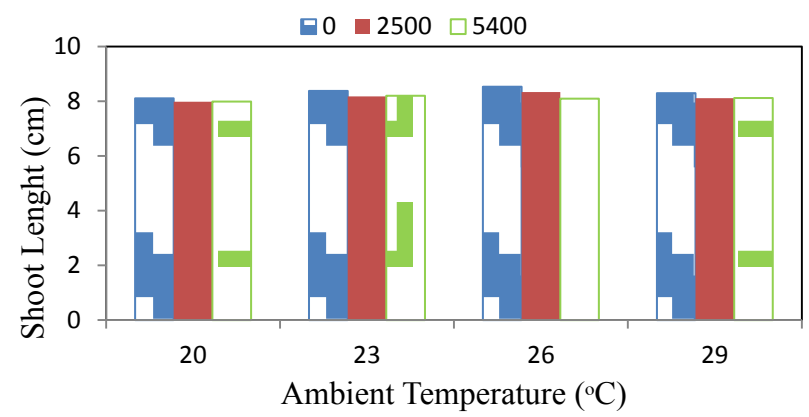

Figure 6: Effect of ambient temperature and light intensity on stem diameter of the grafted cucumber seedlings. acclimatization compared with that of dark condition. These results agreed with those obtained by $[13,27]$ in which the leaf area of grafted cucumber seedlings was increased by light during acclimatization. The results also indicate that the leaf area ranged from 56.074 and $53.214 \mathrm{~cm}^{2}$ at truss and flat tunnel, respectively. The statistical analysis showed that there were significant differences between the temperature treatments, light intensity and type of tunnel shape. The analysis showed also that the interaction between both $\mathrm{ABC}$ were non-significant. On the other hand, the interaction between the effect of both $\mathrm{AB}, \mathrm{AC}$ and $\mathrm{BC}$ on the data were significant.

Shoot dry mass: Table 4 and Figures 13-15 show the shoot dry mass of the grafted cucumber seedlings grown under two types of tunnel (truss and flat) as affected by the ambient temperatures from 20 to $29^{\circ} \mathrm{C}$ and light intensities from 0 to 5400 Lux. It could be seen that the average values of shoot dry mass were 379.522, 393.247, 402.247 and $390.601 \mathrm{mg}$ for the grafted cucumber seedlings grown at 20,23, 26 and $29^{\circ} \mathrm{C}$ ambient temperature, respectively depending on the light intensities and type of tunnel. The results showed that the seedling shoot dry mass increased with increasing the ambient temperature 20 to $26^{\circ} \mathrm{C}$, where, grafting at $26^{\circ} \mathrm{C}$ ambient temperature gave the best results in terms of shoot dry mass for all light intensity and type of tunnel with significant differences. Concerning the effect of light intensity on the shoot dry mass, the results indicate that the average shoot dry mass of the grafted cucumber seedling grown under the truss and flat tunnel shape increases with increasing the light intensity. It indicates that when the light intensity increased from 0 to $5400 \mathrm{Lux}$, the average shoot dry mass of the grafted cucumber seedling significantly increased from 378.286 to $408.228 \mathrm{mg}$. The results also indicate that the shoot dry mass ranged from 396.448 and $388.585 \mathrm{mg}$ in truss and flat tunnels, respectively. The statistical analysis showed that there were significant differences between the temperature, light intensity and type of tunnel shape treatments. The analysis showed also that the interaction between both $\mathrm{AB}$ and $\mathrm{ABC}$ were non-significant. On the other hand, the interaction between the effect of both $\mathrm{AC}$ and $\mathrm{BC}$ on the data were significant.

\section{Grafted-take}

Table 5 and Figures 16-18 show the grafted-take (efficiency of grafting) of the grafted cucumber seedlings grown under two types of tunnel (truss and flat) as affected by the ambient temperatures from 20 to $29^{\circ} \mathrm{C}$ and light intensities from 0 to 5400 Lux. Regarding of the 
Citation: Khater ESG (2017) Effect of Acclimatization Temperature and Light Intensity on the Graft-Take of Cucumber Seedlings. J Environ Anal Toxicol 7: 502. doi: 10.4172/2161-0525.1000502

Page 6 of 10

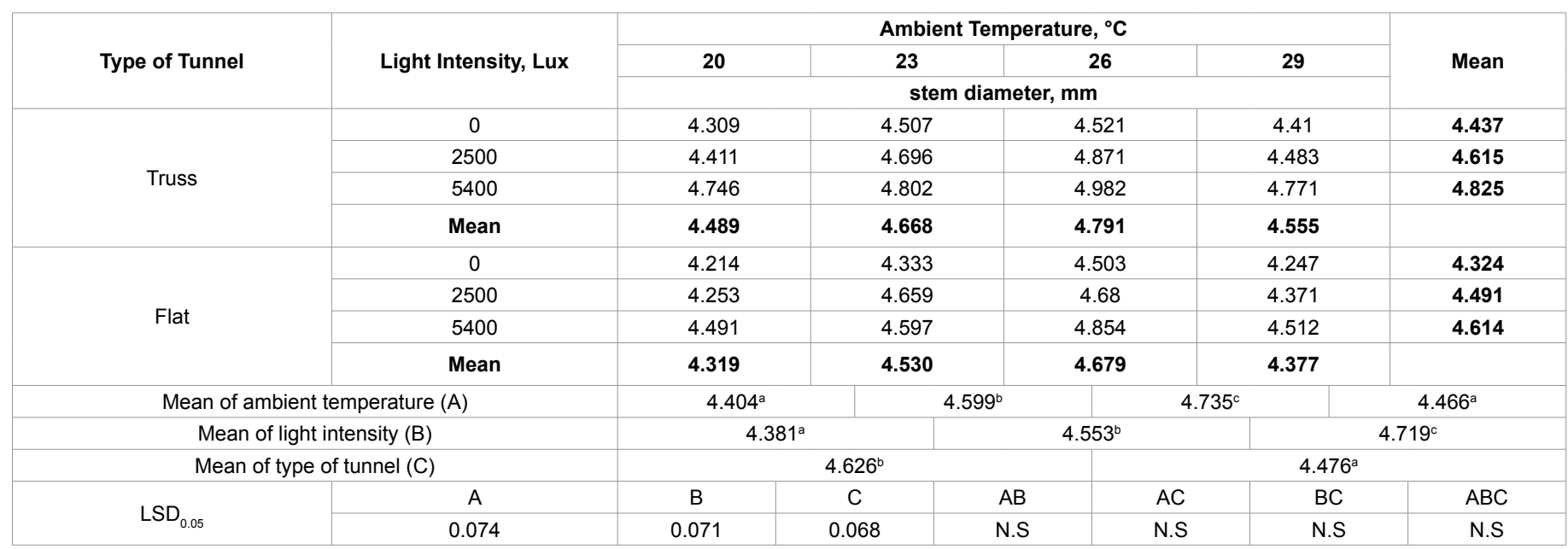

Table 2: Effect of ambient temperature, light intensity and type of tunnel on stem diameter of the grafted cucumber seedlings.

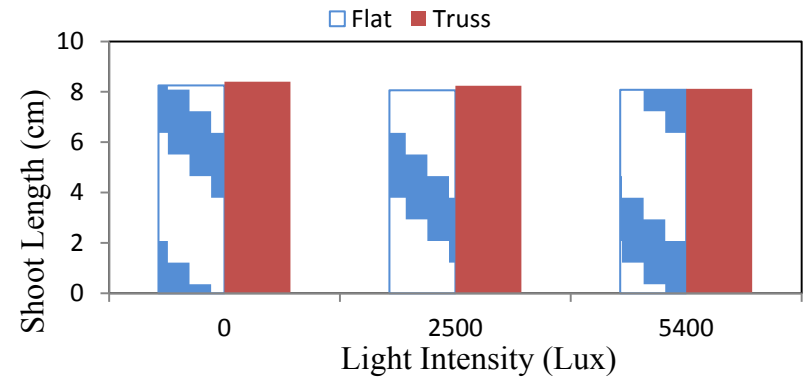

Figure 7: Effect of light intensity and type of tunnel on shoot length of the grafted cucumber seedlings.

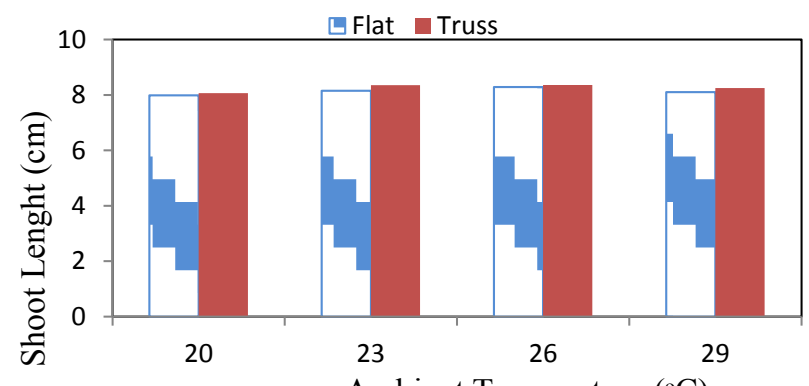

Ambient Temperature $\left({ }^{\circ} \mathrm{C}\right)$

Figure 8: Effect of ambient temperature and type of tunnel on shoot length of the grafted cucumber seedlings.

effect ambient temperature, it could be seen that the average values of grafted-take were $77.998,82.107,84.973$ and $80.892 \%$ for the grafted cucumber seedlings grown at $20,23,26$ and $29^{\circ} \mathrm{C}$ ambient temperature, respectively depending on the light intensities and types of tunnel. The results showed that the seedling grafted-take increased with increasing the ambient temperature 20 to $26^{\circ} \mathrm{C}$, where, grafting at $26^{\circ} \mathrm{C}$ ambient temperature gave the best results in terms of grafted-take for all light intensity and type of tunnel with significant differences. The grafted-take increased by $5.39 \%$, when the ambient temperature increased from 20 to $29^{\circ} \mathrm{C}$ in truss tunnel, where, it increased by $1.60 \%$, when the ambient temperature increased from 20 to $29^{\circ} \mathrm{C}$ in flat tunnel. Meanwhile the light intensity has diverse effect on the grafted-take, where it was 88.651 decreased to $80.069 \%$, when the light intensity increased from 0 to 5400 Lux in truss tunnel, where, it decreased from 82.235 to $74.844 \%$, when

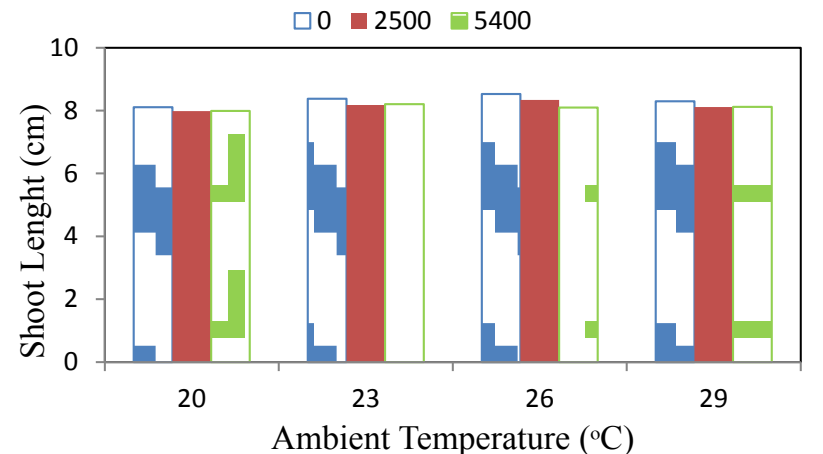

Figure 9: Effect of ambient temperature and light intensity on shoot length of the grafted cucumber seedlings.

the light intensity increased from 0 to 5400 Lux in flat tunnel. Darkness pushes the plant to the vegetative growth, this in turn affect the healing of seedlings during grafting process. These results were in agreement with those obtained by [26]. The statistical analysis showed that there were significant differences between the temperature, light intensity and type of tunnel shape treatments. The analysis showed also that the interaction between $\mathrm{ABC}$ were non-significant. On the other hand, the interaction between the effect of both $\mathrm{AB}, \mathrm{AC}$ and $\mathrm{BC}$ on the data were significant.

Regression analysis was carried out to find a relation between the grafted-take and both ambient temperatures and light intensities. Equations (2, 3 and 4) show the most appropriate form for the relationship between the grafted-take and ambient temperatures at different light intensities.

For 0 Lux light intensity:

$$
G T=68.877+14.484 A T-2.619 A T^{2} \quad \mathrm{R}^{2}=0.97
$$

For 2500 Lux light intensity:

$$
G T=68.426+8.174 A T-1.521 A T^{2} \quad \mathrm{R}^{2}=0.89
$$

For 5400 Lux light intensity:

$$
G T=68.426+8.174 A T-1.521 A T^{2} \quad \mathrm{R}^{2}=0.89
$$

where, GT is the grafted-take of grafted cucumber seedlings, \%; AT is the ambient temperature, ${ }^{\circ} \mathrm{C}$. 
Citation: Khater ESG (2017) Effect of Acclimatization Temperature and Light Intensity on the Graft-Take of Cucumber Seedlings. J Environ Anal Toxicol 7: 502. doi: 10.4172/2161-0525.1000502

Page 7 of 10

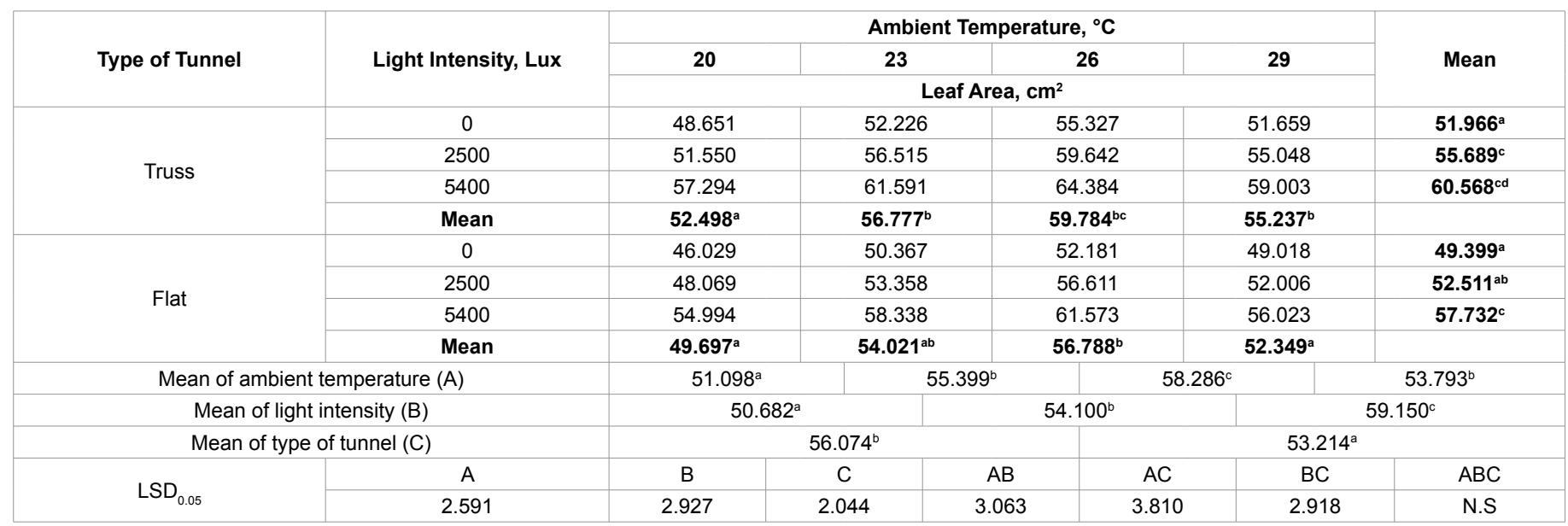

Table 3: Effect of ambient temperature, light intensity and type of tunnel on leaf area of the grafted cucumber seedlings.

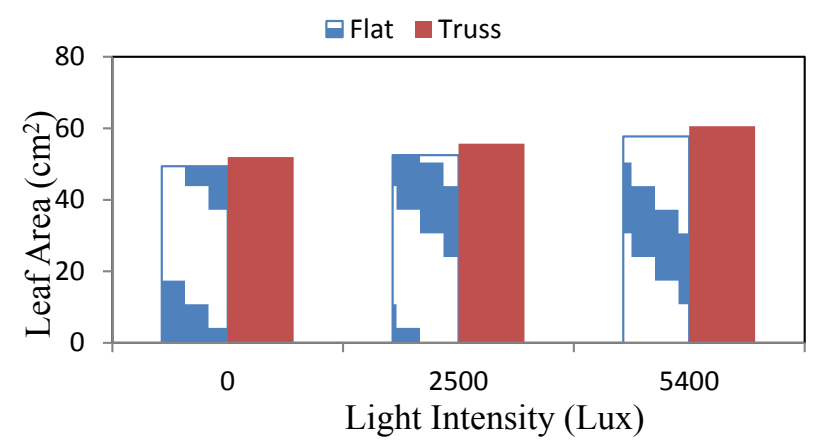

Figure 10: Effect of light intensity and type of tunnel on leaf area of the grafted cucumber seedlings.

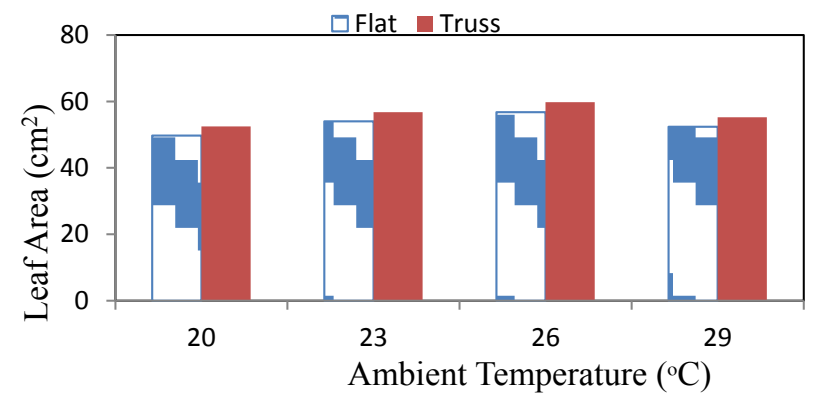

Figure 11: Effect of ambient temperature and type of tunnel on leaf area of the grafted cucumber seedlings.

\section{Energy consumption}

Figure 19 shows the effect of room temperature and light intensity on the energy consumption. It is clear that the energy consumed in production grafted cucumber seedlings decreased with increasing ambient temperature from 20 to $29^{\circ} \mathrm{C}$ and decreased light intensity from 5400 to 0 Lux. It could be seen that the energy consumed decreased from 44.052 to $32.532,50.356$ to 38.836 and 56.660 to $45.140 \mathrm{~kW}$ per 1000 seedlings at 0,2500 and 5400 Lux light intensities, respectively, when the ambient temperature increasing from 20 to $29^{\circ} \mathrm{C}$. Meanwhile the energy consumed increased from 44.052 to $56.660,40.212$ to $52.820,36.372$ to 48.980 and 32.532 to $45.140 \mathrm{~kW}$ per 1000 seedlings at $20,23,26$ and $29^{\circ} \mathrm{C}$ ambient temperatures, respectively, when the light intensity increasing 0 to 5400 Lux.

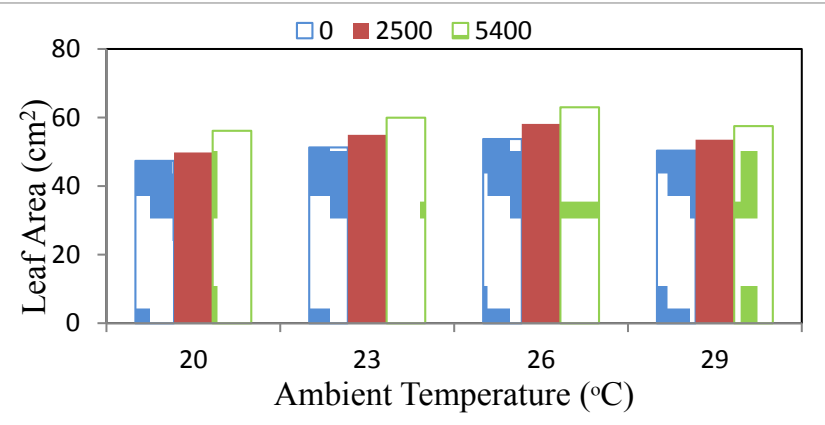

Figure 12: Effect of ambient temperature and light intensity on leaf area of the grafted cucumber seedlings.

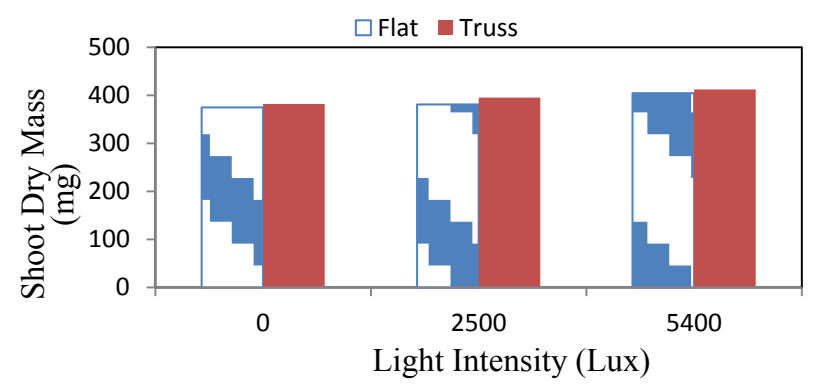

Figure 13: Effect of light intensity and type of tunnel on shoot dry mass of the grafted cucumber seedlings.

\section{Conclusion}

The experiment was carried out to optimize the environmental condition for best grafting by control the temperature and light of grafting conditions. To achieve that was study the effect of ambient temperatures $\left(20,23,26\right.$ and $\left.29^{\circ} \mathrm{C}\right)$, light intensity $(0,2500$ and 5400 Lux) and type of tunnel (truss and flat) on stem diameter, shoot length, leaf area, shoot dry mass and grafted-take. The obtained results can be summarized as follows:

- The temperature distribution patterns appear as a concave shape where, the temperature increased toward the center of the flat tunnel which varies slightly from 20.291 to 21.053 , 23.526 to $25.761,26.893$ to 29.517 and 29.149 to $33.729^{\circ} \mathrm{C}$ at $20,23,26$ and $29^{\circ} \mathrm{C}$ ambient temperature, respectively and it increased from 20.259 to $20.909,23.271$ to $24.300,27.811^{\circ} \mathrm{C}$ 
Citation: Khater ESG (2017) Effect of Acclimatization Temperature and Light Intensity on the Graft-Take of Cucumber Seedlings. J Environ Anal Toxicol 7: 502. doi: 10.4172/2161-0525.1000502

Page 8 of 10

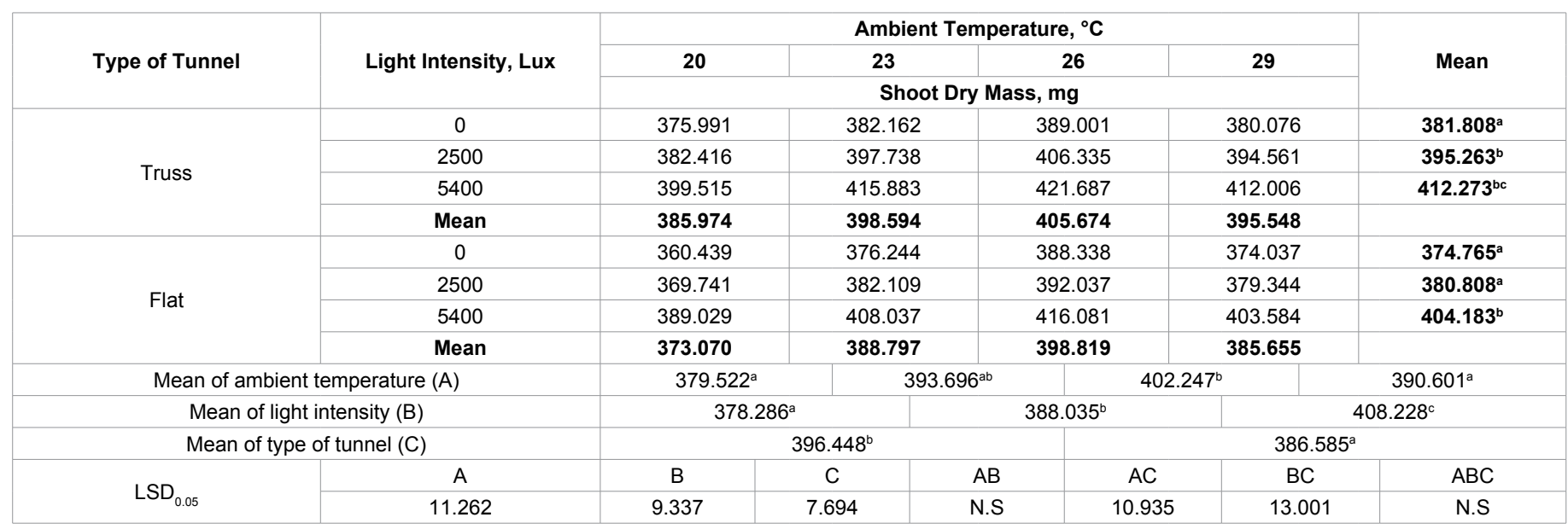

Table 4: Effect of ambient temperature, light intensity and type of tunnel on shoot dry mass of the grafted cucumber seedlings.

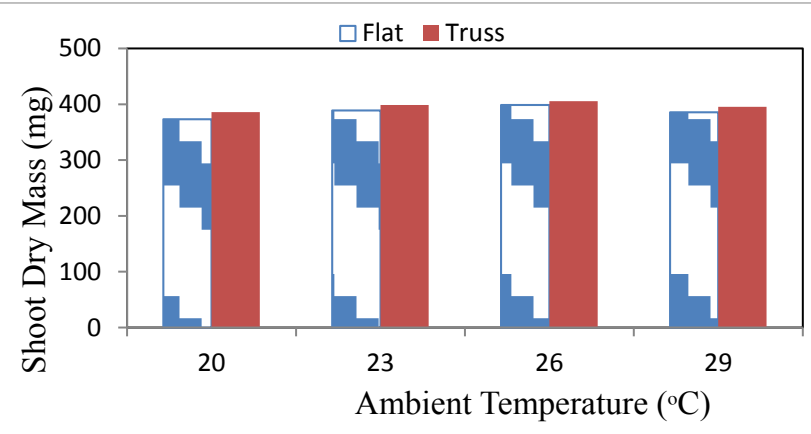

Figure 14: Effect of ambient temperature and type of tunnel on shoot dry mass of the grafted cucumber seedlings.

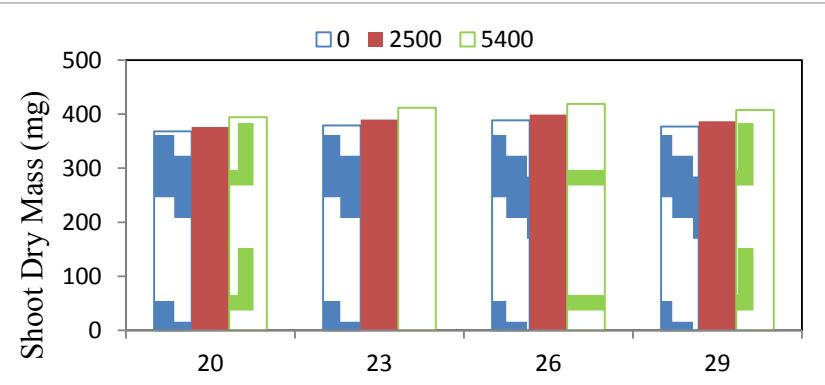

Ambient Temperature $\left({ }^{\circ} \mathrm{C}\right)$

Figure 15: Effect of ambient temperature and light intensity on shoot dry mass of the grafted cucumber seedlings.

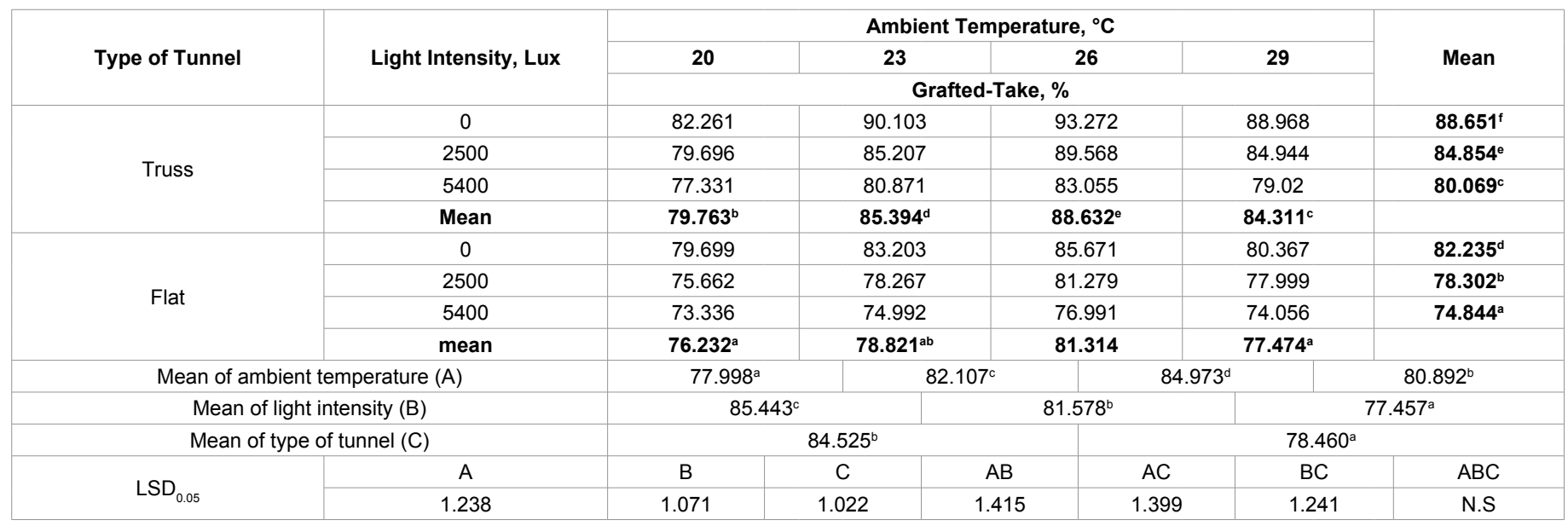

Table 5: Effect of ambient temperature, light intensity and type of tunnel on grafted-take of the grafted cucumber seedlings.

at 26 and 29.372 to $30.818^{\circ} \mathrm{C}$ at $20,23,26$ and $29^{\circ} \mathrm{C}$ ambient temperature, respectively in truss tunnel.

- The highest value of the stem diameter of the grafted cucumber seedlings $(4.735 \mathrm{~mm})$ was obtained at ambient temperature of $26^{\circ} \mathrm{C}$. While the highest value of the stem diameter of the grafted cucumber seedlings $(4.719 \mathrm{~mm})$ was found at light intensity 5400 Lux.

- The seedling shoot length increased with increasing the ambient temperature 20 to $26^{\circ} \mathrm{C}$, where, grafting at $26^{\circ} \mathrm{C}$ ambient temperature gave the best results in terms of shoot length for all light intensity and type of tunnel with significant differences. The shoot length ranged from 8.254 and $8.131 \mathrm{~cm}$ at truss and flat tunnel, respectively.

- The leaf area and shoot dry mass ranged from 56.074 and $53.214 \mathrm{~cm}^{2}$ and 396.448 and $388.585 \mathrm{mg}$ at truss and flat tunnel, respectively.

- The grafted-take increased by 5.39 and $1.6 \%$, when the ambient temperature increased from 20 to $29^{\circ} \mathrm{C}$ in truss and flat tunnels. 
Citation: Khater ESG (2017) Effect of Acclimatization Temperature and Light Intensity on the Graft-Take of Cucumber Seedlings. J Environ Anal Toxicol 7: 502. doi: 10.4172/2161-0525.1000502

Page 9 of 10

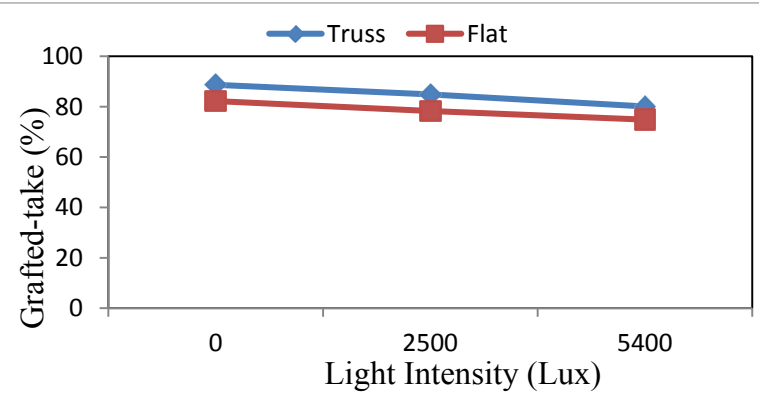

Figure 16: Effect of light intensity and type of tunnel on grafted-take of the grafted cucumber seedlings.

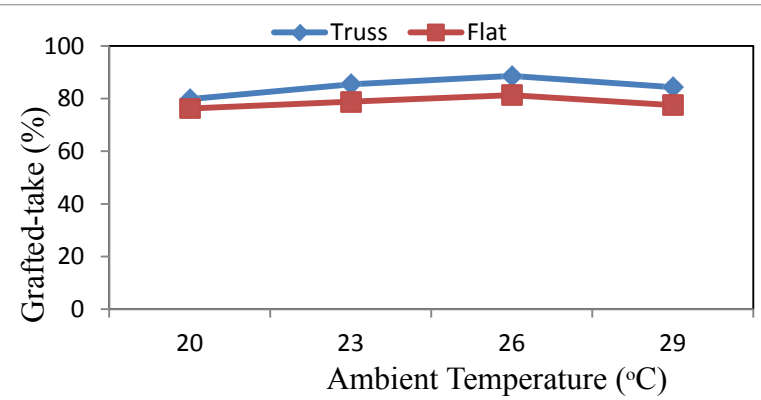

Figure 17: Effect of ambient temperature and type of tunnel on grafted-take of the grafted cucumber seedlings.

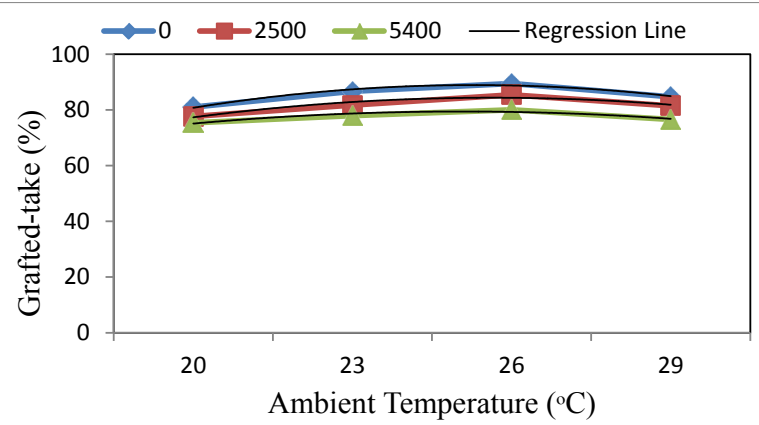

Figure 18: Effect of ambient temperature and light intensity on grafted-take of the grafted cucumber seedlings.

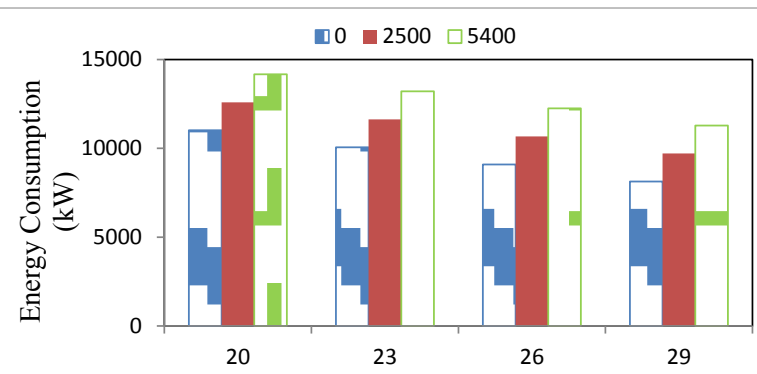

Ambient Temperature $\left({ }^{\circ} \mathrm{C}\right)$

Figure 19: Energy consumed in production grafted cucumber seedlings.

Meanwhile the light intensity has diverse effect on the graftedtake, where it was decreased from 88.651 to 80.069 and 82.235 to $74.844 \%$, when the light intensity increased from 0 to 5400 Lux in truss and flat tunnels.

The energy consumed decreased from 44.052 to $32.532,50.356$ to 38.836 and 56.660 to $45.140 \mathrm{~kW}$ per 1000 seedlings at 0,2500 and 5400 Lux light intensities, respectively, when the ambient temperature increasing from 20 to $29^{\circ} \mathrm{C}$.

\section{References}

1. FAO (2015) Statistics at FAO. Available online: www.fao.org/statistics/en

2. CAPMS (2014) Annual year book for general statistics. Egypt: Central Agency for Public Mobilization and Statistics of ARE.

3. Kubota C, McClure MA, Kokalis-Burelle N, Bausher MG, Rosskopf EN (2008) Vegetable grafting: History, use, and current technology status in north America. Hort Science 43: 1664-1669.

4. Lee JM, Kubota C, Tsao SJ, Bie Z, Hoyos Echevarria P, et al. (2010) Current status of vegetable grafting: diffusion, grafting techniques, automation. Sci Hortic 127: 93-105.

5. Savvas D, Colla G, Rouphael Y, Schwarz D (2010) Amelioration of heavy metal and nutrient stress in fruit vegetables by grafting. Scientia Hortiult 127: 156161.

6. Schwarz D, Rouphael Y, Colla G, Venema JH (2010) Grafting as a tool to improve tolerance of vegetables to abiotic stresses: thermal stress, water stress and organic pollutants. Scientia Horticult 127: 162-171.

7. Louws FJ, Rivard CL, Kubota C (2010) Grafting fruiting vegetables to manage soilborne pathogens, foliar pathogens, arthropods and weeds. Scientia Horticult 127: 127-146.

8. Sakata Y, Takayoshi O, Mitsuhiro S (2007) The history and present state of the grafting of cucurbitaceous vegetables in Japan. Acta Horticult 731: 159-170.

9. Lee JM, Oda M (2003) Grafting of herbaceous vegetable and ornamental crops. Hortic Rev 28: 61-124.

10. Rivero M, Ruiz JM, Romero L (2003) Role of grafting in horticultural plants under stress conditions. Food Agric Environ 1: 70-74.

11. Mun $\mathrm{BH}$, Jang $Y A$, Goto $E$, Ishigami $Y$, Chun $\mathrm{CH}$ (2011) Measurement System of whole-canopy dioxide exchange rates in grafted cucumber transplants in which scions were exposed to different water regimes using a semi-open multichamber. Sci Hort 130:607-614.

12. Nobuoka T, Nishimoto T, Toi $K(2005)$ Wind and light promote graft-take and growth of grafted tomato seedlings. J Japan Soc Hort Sci 74: 170-175.

13. Jang Y, Goto E, Ishigami Y, Mun B, Chun C (2011) Effects of Light Intensity and Relative Humidity on Photosynthesis, Growth and Graft-take of Grafted Cucumber Seedlings during Healing and Acclimatization. Hort. Environ. Biotechnol 52: 331-338.

14. Kim YH (2000) Effects of air temperature, relative humidity and photosynthetic photon flux on the evapotranspiration rate of grafted seedlings under artificial lighting. In: Kubota C, Chun C (eds.). Transplant production in the $21^{\text {st }}$ century. Kluwer Academic Publishers, The Netherlands, pp: 91-97.

15. Köse B (2014) Effect of Light Intensity and Temperature on Growth and Quality Parameters of Grafted Vines. Not. Bot. Horti Agrobo 42: 507-515.

16. Oztürk A, Serdar U (2011) Effects of different nursery conditions on the plan development and some leaf characteristics in Chestnuts (Castanea sativa Mill.). Aust J Crop Sci 5:1218-1223.

17. Agaoglu SY, Ayfer M, Fidan F, Koksal I, Celik M, et al. (1995) Genera Horticulture. Ankara University Agricultural Faculty Press, Volume No: 1009 Ankara, Turkey, p: 283.

18. Uzun S, Demir Y (1996) The effect of temperature on plant growth, development and productivity (II. Growth). J Agr Fac OMU 11: 201-212.

19. Amaki W, Hirai T (2008) Photomorphogenic responses of horticultural crops to monochromatic light. In: Goto E (ed.), Agri-photonics - Advances in plant factories with LED lighting 2008: 29-40.

20. Fukuda N, Fujita M, Ohta Y, Sase S, Nishimura S, et al. (2008) Directional blue light irradiation triggers epidermal cell elongation of abaxial side resulting in inhibition of leaf epinasty in geranium under red light condition. Sci Hort 115: 176-182.

21. Fang W, Jao RC (2000) A review on artificial lighting of tissue cultures and transplants. In: Kubota C, Chun C (eds.), Transplant production in the $21^{\text {st }}$ century. Kluwer Academic Publishers, Dordrecht, The Netherlands. 
Citation: Khater ESG (2017) Effect of Acclimatization Temperature and Light Intensity on the Graft-Take of Cucumber Seedlings. J Environ Anal Toxicol 7: 502. doi: 10.4172/2161-0525.1000502

Page 10 of 10

22. Hoagland DR, Arnon DI (1950) The water culture method for growing plants without soil. Univ of California, Agric. Exp Sta Cir, p: 347.

23. Snedecor GW, Cochran WG (1980) Statistical Methods. 7th edn. lowa State University Press, Ames, lowa, USA.

24. Gomez KA (1984) Statistical Procedures for Agricultural Research. 2nd edn. John Wiley \& Sons, New York, USA, p: 680.
25. Bekhradi F, Kashi A, Delshad M (2011) Effect of three cucurbits rootstocks on vegetative and yield of 'Charleston Gray' watermelon. International Journal of Plant Production 5: 105-110.

26. Sabahy AA (2014) Studies on design and management of soilless culture systems. PhD Thesis in Agric. Eng., Fac Agric Moshtohor, Benha Univ, Egypt.

27. Oguchi R, Hikosaka K, Hirose T (2003) Does the photosynthetic lightacclimation need change in leaf anatomy? Plant Cell Environ. 26: 505-512. 